\title{
Importance of water consumption for calcium nutrition of trees
}

\author{
A. Vigouroux ${ }^{1}$, C. Bussi ${ }^{2}$ and J.F. Berger ${ }^{1}$ \\ 1 INRA, Botanique et Pathologie Végétale-ENSA, 34060 Montpellier Cedex, and \\ 2INRA, SRIV, Domaine-de-Gotheron, 26320 St-Marcel-les-Valence, France
}

\section{Introduction}

Because of the relationship between peach tree susceptibility to a bacterial dieback and the edaphic conditions of the orchards (Vigouroux and Huguet, 1977), it is necessary to specify the effect of the tree's calcium nutrition on this relationship.

An initial profile analysis in acid predisposing soils suggested several factors inducing an inability to provide an adequate water supply that might result in a predisposing effect on the trees to bacterial dieback. Preliminary experiments were then conducted in large weighable containers to confirm and quantify these observations. Results indicated a marked effect of water consumption on tree calcium nutrition (Vigouroux et al., 1987).

Unfortunately, in these preliminary experiments, trees were irrigated with tap water which was found to be calcareous. Thus, it was necessary to determine the respective role of water and calcium availability in the variations of the calcium content of the trees. For this purpose, a new experiment was undertaken with the same acid soil and the same container culture conditions but using 2 treatments: calcareous and demineralized water, each applied at 2 levels of irrigation. Limed and natural soils were also compared to estimate the effect of an increase of the availability of calcium in the soil. This paper reports the results.

\section{Materials and Methods}

Peach tree scions (Prunus persica L. Batch, cV May-Crest on GF 305 rootstock) were cultivated for $1 \mathrm{yr}$, each one in a $250 \mathrm{I}$ container filled with acid soil. The soil was a pebbly loamy sandy material originating from the $0-30 \mathrm{~cm}$ horizon of the old fluvial-glacial RISS terrace of the Rhone valley (Bornand, 1978). Water pH was 6.0 (for detailed characteristics see Vigouroux et al., 1987).

Irrigation was provided by 4 parallel pipe circuits that delivered both kinds of water, each at 2 levels. The 1st level corresponded to MET (maximum evapotranspiration) and the 2nd was adjusted to $70 \%$ of MET to induce slight water stress. Irrigation level treatments were applied only from early July to avoid differences between tree development according to treatments. As noted previously, the calcareous water was the city tap water containing $120 \mathrm{mg}$ of $\mathrm{Ca} / \mathrm{l}$ and the demineralized water was deionized by a large resin device (Sadon Co., Demino 5000 model). One gram of $\mathrm{CaO} / \mathrm{kg}$ of soil was added to the soil to be amended. 
There were 6 treatments: 2 irrigation levels supplied with calcareous water on the control soil or supplied with deionized water on the control and on the limed soil. For each treatment, 12 trees were used; each one was analyzed separately.

The effect of the treatment on the total calcium content of the tree tissues was estimated by the mineral analysis of twig bark (the tissue in which develops Pseudomonas syringae pv persicae, the infectious agent of the studied disease). For each tree, 14 small twigs, well spread on the crown (Cummings, 1973), were sampled for analysis in early December. After removing the bark and drying, calcium content was determined by flame photometry.

\section{Results}

Mean values of the twig calcium contents are presented in Table I. Under all conditions tested, higher irrigation and water consumption were associated with a significant and clear-cut increase of the calcium content. In comparison, both kinds of calcium supply induced no noticeable variation of the content. At the low level of irrigation, a significatively lower $\mathrm{Ca}$ content was noted with the calcareous water compared with deionized water in acid soil but this result is to be associated to a slight failing of the irrigation device which delivered, for the low level of calcareous water, a smaller amount of water than planned. In fact, this accidental effect further confirms the general result.

\section{Discussion arid Conclusion}

As already established for various plants (Epstein, 1972; Bangerth, 1979; Kirkby, 1979; Clarksorı and Hanson, 1980), water flow associated with water consumption appears to have a dramatic influence on uptake and transportation of calcium to the top of trees, like peach, independently of the available amount of this cation in the soil solution (above some minimum threshold).

Some observations in experimental plots in an open field confirm these results obtained with container material. We also think that this is probably true for all species including forest trees, and this suggests important indirect effects of drought on a tree's development and survival because of the importance of calcium for physiological processes, including resistance to parasites.

Table I. Effect of water consumption and 2 kinds of calcium supply on calcium content of peach twig bark.

\begin{tabular}{llll}
\hline \multirow{2}{*}{ Water } & Soil & \multicolumn{2}{l}{ Level of irrigation } \\
\cline { 3 - 4 } & & MET (100\%) & slight stress (70\%) \\
\hline Calcareous ${ }^{1}$ & acid & $3.55^{3} \mathrm{C}$ & $2.26 \mathrm{a}$ \\
Deionized & acid (control) & $3.33 \mathrm{C}$ & $2.57 \mathrm{~b}$ \\
& limed $^{2}$ & $3.50 \mathrm{C}$ & $2.65 \mathrm{~b}$ \\
\hline
\end{tabular}

1 Tap water containing $120 \mathrm{mg}$ of $\mathrm{Ca} /$.

2 Soil limed by addition of $1 \mathrm{~g}$ of $\mathrm{CaO} / \mathrm{kg}$.

3 Mean of 14 twigs/tree and 12 trees. Means are classed and distinguished (different letters) according to Newman and Keul's range test, $5 \%$ level. 


\section{References}

Bangerth B. (1979) Calcium-related physiological disorders of plants. Annu. Rev. Phytopathol. 17, 97-112

Bornand M. (1978) Alteration des matériaux fluvio-glaciaires; genèse et évolution des sols sur terrasses quaternaires dans la moyenne vallée du Rhône. Ph.D. Thesis, Université des Sciences et Techniques du Languedoc, Montpellier

Clarkson D.T. \& Hanson J.B. (1980) The mineral nutrition of higher plants. Annu. Rev. Plant Physiol. 31, 239-298

Cummings G.A. (1973) The distribution of elements in 'Elberta' peach tree tissues and the infuence of potassium and magnesium fertilization. J. Am. Soc. Hortic. Sci. 98, 474-477

Epstein E. (1972) In: Mineral Nutrition of Plants: Principales and Perspectives. John Willey \& Sons, New York, pp. 412

Kirkby E.A. (1979) Maximizing calcium uptake by plants. Commun. Soil. Sci. Plant Anal. 10, 89-113

Vigouroux A. \& Huguet C. (1977) Influence du substrat de culture sur la sensibilité du pêcher au dépérissement bactérien. C.R. Acad. Agric. Fr. 63, 1095-1103

Vigouroux A., Berger J.F. \& Bussi C. (1987) La sensibilité du pêcher au dépérissement bactérien en France: incidence de certaines caractéristiques du sol et de l'irrigation. Relation avec la nutrition. Agronomie 7, 483-495 